\title{
HAPPINESS AS A PERSONIFIED VALUE DIMENSION OF PERSON
}

In Happiness And Contemporary Society : Conference Proceedings Volume (Lviv, March, 20-21, 2021). Lviv: SPOLOM, 2021. P. 134-136. https://doi.org/10.31108/7.2021.29

ISBN 978-966-919-697-2

\section{ЩАСТЯ ЯК ПЕРСОНІФІКОВАНИЙ ЦІННІСНИЙ ВИМІР ЛЮДИНИ}

// Щастя та сучасне суспільство : збірник матеріалів міжнародної наукової конференції (Львів, 20-21 березня 2021 р.). - Львів : СПОЛОМ, 2021. С. 134-136. https://doi.org/10.31108/7.2021.29

ISBN 978-966-919-697-2 


\title{
HNASEVYCH Nadiya
}

PhD, Associate Professor,

Associate Professor at the Department of Philosophy and Political Science

Western Ukrainian National University (Ternopil, Ukraine)

\section{HAPPINESS AS A PERSONIFIED VALUE DIMENSION OF PERSON}

\author{
ГНАСЕВИЧ Надія \\ кандидат філософських наук, дочент, \\ доиент кафедри філософії та політології \\ Західноукраӥнський начіональний університет (м.Тернопіль, Україна)
}

\section{ЩАСТЯ ЯК ПЕРСОНІФІКОВАНИЙ ЦІННСНИЙ ВИМІР ЛЮДИНИ}

У тезах обгрунтовані теоретичні позиції щодо розуміння феномену щастя у ціннісно-смислових характеристиках відповідно «ціннісним викликам» часу. Сучасна проблематика щастя базується на апології людського в людині, що має резонанс 3 позиціями філософії культури, філософії життя, філософської антропології. Авторська увага зосереджена на концептуальному представлені категорії «щастя» 3 огляду на динамічні процеси безперервного становлення, вдосконалення і творчого саморозвитку людини.

У дослідженні наголошено, що змістові характеристики феномена щастя відповідні його «ірраціональній» природі: щастя належить до смислових універсалій, за допомогою яких людина одержує можливість повноцінно переживати своє життя. Цінність щастя виступає надіндивідуальною сутністю людини, завдяки якій людина зростає до вершин душевної свободи, переживаючи особистісні смисли у персоніфікованому вимірі.

Ключові слова: щастя, цінності, смисли, людина, свобода, творчість, персоніфікація, суб' єктивність, індивідуальність.

The desire for happiness is inherent in people. It is the main driver of behaviour and the pursuit of perfection and fullness of human self-expression. The disappearance of this landmark for any reason leads to the collapse of the entire personality system. The phenomenon of happiness belongs to modern rethought actualities in accordance with the "axiological challenges" of the time.

The problem of happiness in the modern dimension of human life is gaining increasing attention in the interdisciplinary scientific research on human being. The nature of values and culture, happiness and spiritual forces of man in the worldview aspect acquire further understanding in the context of explaining modern practices of existence. The conceptualization of the phenomenon of happiness in the characteristics of human cultural development is based on the apology of the human side in man, which resonates with the positions of philosophy of culture, philosophy of life, philosophical anthropology. Thus, in modern philosophical anthropology, happiness as a felicitological aspect of human existence is considered in the plane of dialectical interconnectedness 
with creative intentions and the situation of axiological choice in human life, in the context of representation as an act of personal self-expression, personal worldview.

The problem of happiness is combined in a dynamic perspective with the interpretation of the processes of continuous formation, improvement and creative selfdevelopment of man: without an inner sense of happiness, the disclosure of human spiritual powers, it is impossible to see the beauty of life and find meaning in life. Disclosure of the meaning of the concept of "happiness" through the categories of "value", "creativity", "sense" means that a person can create a multifaceted world of mental well-being, and creative potential of the person indicates that the nature of happiness is distinct from the processes of conscious and logical expression of will, thanks to which the world of human feeling of happiness is constantly objectified in renewed value-semantic beliefs, assessments and meanings.

The nature of happiness is "irrational", happiness belongs to those semantic universals by which a person gets the opportunity to fully experience own life. Happiness belongs to the meaning-forming values, among which are the values of creation, the values of attitudes. The value of happiness becomes meaningful to a person when a person experiences an awareness of the significance and joy of something. It is impossible to learn the feeling of happiness - happiness must be experienced.

On the basis of ideas about happiness, values and semantic landmarks as idealmetaphorical formations, symbolic landmarks of life and activity behavioral tactics are set. Felicitological assessments of man are always loaded with meaning: happiness as a value is a kind of cultural form of fixation and generalization of the meanings of human existence, including such semantic landmarks as life, goodness, beauty, freedom and others, which belong to the basic achievements of human culture. The famous scientist V. Frankl reduces the semantic objectivity of man to: meaning in activity, meaning in experience, meaning in love and happiness [2, p. 101].

The value of happiness is the supra-individual essence of man, thanks to which man grows to the heights of spiritual freedom, at the same time having a fundamentally individual experience. In each person, the individual experience of happiness is based on subjective significance in relation to the dominant value which brings a personalized character to the personal meaning of human existence, serving to harmonize the inner world of "Self" within a particular culture. C. Jung showed that the human "Self" is a concentration of personal characteristics at the top of universal depths in the psyche of the individual [3, p. 68]. Happiness in the individual human psyche acquires transpersonal expression, along with the phenomena of freedom, love, dignity, the right to be different. Happiness is an expression of the translation of the personal "Self" into the space of self-activity of man and his free emotional state. Happiness reflects "the human dimension of feeling." In the dimensions of psychological theory, the problem of happiness is often considered in the context of the contradiction of the situation, the struggle of motives, aspects of the implementation of human choice. The definition of happiness indicates the problem of human existence, compliance with the dynamic balance of its essential "Self", the dialectical unity of subjective determination and the objectified world of things, situations, circumstances. In fact, the problem of happiness indicates the praxis of human existence and consciousness, the identification of the noumenal world of ideas, signs, values, meanings, senses. According to the theoretical position, in the broadest sense, we can say that happiness is not so much a feeling as it is 
a person. The question is how happy a person is. This formulation of the question actualizes the understanding of happiness as creativity.

The value-semantic field of happiness is the object of creativity, where images and ideas, symbols and concepts, meanings and beliefs are born. Man is able to feel the whole world of happiness within his individuality. Happiness in its essence appears as the constitution of being in consciousness, the "transcendental subjectivity" of man. In this regard, a person is able to represent oneself in the dimensions of culture, mental freedom and axiological choice.

\section{REFERENCES}

1. Tabachkovskij V. G. (1993). Chelovecheskoe mirootnoshenie: dannost'ili problema? Kyïv: Naukova dumka, $245 \mathrm{p}$.

2. Frankl V. (1990). Chelovek v poiskah smysla. Moskva: Progress, 368 p.

3. Jung C. (1991). Podhod k bessoznatel'nomu //Arhetip i simvol. Moskva : Renessans, p. $65-84$ 